\title{
微細気孔性アルミナ多孔体の製造法
}

関 八千穂・小瀬三郎・児玉皓 雄・門田正胤

小倉透・谷本一美・松原一郎

(大阪工業技術試験所，563 池田市緑丘 1-8-31)

\section{Fabrication Method of Porous Alumina Compacts Containing Submicron Pores}

\author{
Yachiho SEKI, Saburo KOSE, Teruo KODAMA, Masatane KADOTA, Toru OGURA, \\ Kazumi TANIMOTO and Ichiro MATSUBARA
}

(Government Industrial Research Institute, Osaka, 1-8-31, Midorigaoka, Ikeda-shi

563)

\begin{abstract}
The purpose of the present investigation was to establish the production technique of porous compacts of ceramics containing fine pores. Alumina powders of various particle sizes blended with solvent were pressed under $300 \mathrm{~kg} / \mathrm{cm}^{2}$ and then fired at $1000^{\circ}-1375^{\circ} \mathrm{C}$, and the characteristics of the obtained compacts were measured. Combination of ultrafine alumina having primary particle diameter of $20 \mathrm{~nm}$ with liquid paraffin (viscosity at $40^{\circ} \mathrm{C}$ was $14 \mathrm{cSt}$, quantity was 3.5 times of the true volume of alumina) gave highly porous compacts containing fine pores. However the ultrafine alumina powder had to be pretreated by water to prevent cracking in firing. Porosity and specific surface area were $78 \%$ and $53 \mathrm{~m}^{2} / \mathrm{g}$, respectively, for the compact fired at $1000^{\circ} \mathrm{C}$, and $66 \%$ and $6 \mathrm{~m}^{2} / \mathrm{g}$ for that at $1350^{\circ} \mathrm{C}$. Pore diameter in the compacts fired at $1000^{\circ}$ and $1350^{\circ} \mathrm{C}$ were less than $12 \mu \mathrm{m}$ and distributed having peaks at 0.03 and $0.26 \mu \mathrm{m}$, respectively.
\end{abstract}

[Received February 1, 1988 ; Accepted April 26, 1988]

Key-words : Forming of ultrafine powder, Porous compacts, Pore size distribution, Specific surface area

\section{1. 緒 言}

超微粒子製造法 ${ }^{1)}$ の進歩に伴い, アルミナ, シリカ, チタニア，マグネシアなどのセラミックス超微粉体が入 手できるようになった。 これら超微粉体の利用技術はま だ未熟であり，特に加工して軽焼結体の形で利用する方 法は，ほとんど手つかずの状態である2). 軽焼結体, 特 に多孔性軽焼結体は膨大な内部表面積を保有する新しい 材料であり, 触媒, 電池電極, 検知器, フィルター, 気 体貯蔵等への利用の可能性を秘めている3 . このため, 超微粉体の成形法の確立は急務と言える.

従来の多孔体製造技術は，焼成工程で消失する有機系 添加物又は基材が，連続相であるか否かにより，二つの タイプに大別できる. 第 1 のタイプはスコットフォーム を基材とし，これにセラミックス粉体をコーチングして から焼成する方法 ${ }^{4)}$, あるいはウレタンプレポリマーと セラミックスの混合物に, 多量の水を添加したときの発 泡反応を利用して多孔化する方法 ${ }^{5}$ であり, 第 2 の夕イ プはセラミックス粉体に有機系粉体を添加し, 焼成する 方法である，ただし，これらの方法は，七ラミックス成 形体を多孔化する方法ではあっても, 微細気孔を導入す る方法として適しているとは言えない。

本報では，微細気孔性セラミックス多孔体の製造を目 的亡する媒液蒸発法を提案する. 微細気孔を導入するた めには, 本方法で原料は微粉体又は超微粉体とし, 添加
物は液体とした. 実験の結果, 超微粉アルミナに対して, 多量の成形用媒液が添加でき, 焼成後, 焼結体内に多量 の気孔が形成され, また, 気孔径が微細であることも明 らかになったので報告する。

\section{2. 実験方法}

\section{1 アルミナ}

アルミナとしては, 微粉体（平均粒径及び BET 法に よる比表面積は，それぞれ $2.5 \mu \mathrm{m}, 0.4 \mu \mathrm{m}$ 及び 3 $\mathrm{m}^{2} / \mathrm{g}, 6 \sim 7 \mathrm{~m}^{2} / \mathrm{g}$ : 昭和軽金属製) 及び超微粉体を用い た. 超微粉体は気相分解法により製造したアルミナ超微 粉体 (西独デグサ製) であり，その 1 次粒子の平均径は 約 $20 \mathrm{~nm}, \mathrm{BET}$ 法による比表面積は $100 \pm 15 \mathrm{~m}^{2} / \mathrm{g}$, ア ルミナ含有率は $99.6 \%$ 以上である.

\section{2 前処理}

入手したままのアルミナ超微粉体は, かさ高く取り扱 いに不便なため, いったん, 水と混合し濃厚なスラリ一 とした後, 乾燥し, 乳鉢を用いて粉砕した.これにより, かさ密度は $0.06 \mathrm{~g} / \mathrm{cm}^{3}$ から $0.37 \mathrm{~g} / \mathrm{cm}^{3}$ に増大した. 超 微粉以外のアルミナは前処理をしなかった.

エタノール, ベンゼン, n-ヘキサンなどによる前処理 によっても, かさ密度は増大した.しかしそれによって, 本来の目的である亀裂のない成形体は得られなかった。

\section{3 成形用媒液}


成形用媒液としては水，メタン誘導体，ベンゼン誘導 体，シクロパラフィン誘導体及びシリコーン油の中から 適宜選んだ。メタン誘導体としては，流動パラフィン， エタノール,ブタノール, オレイン酸, エチレングリコー ル及びグリセリンを，ベンゼン誘導体としてはキシレン を,シクロパラフィンとしてはシクロヘキサンを用いた。

流動パラフインは，昭和シェル石油製オンジナオイル $\left(40^{\circ} \mathrm{C}\right.$ における粘度が $14 \mathrm{cSt}$ ，食品添加物合格品）で あり，シリコーン油は，信越化学から恵与を受けたジメ チルシリコーン $(\mathrm{KF}-96)$ である。

\section{4 成 形}

所定量のアルミナと成形助㓮とを混合したあと，一軸 加圧式プレスを用いて，50 300 kg/ $\mathrm{cm}^{2}$ の圧力で 1 分 間加圧して成形した。グリーン成形体の大きさは $2 \times 5$ $\times 0.8 \sim 1.7 \mathrm{~cm}$ とした.

\section{5 焼成}

グリーン成形体は，エレマ電気炉を用いて大気中で焼 成した. 昇温速度は, 室温から $300^{\circ} \mathrm{C}$ までを $11^{\circ} \mathrm{C} / \mathrm{h}$ と し， $300^{\circ} \mathrm{C}$ から焼成上限温度までを $70^{\circ} \mathrm{C} / \mathrm{h}$ とした。焼 成の上限温度は $1000^{\circ} \sim 1375^{\circ} \mathrm{C}$ とし，全焼成時間は 48 時間とした。

\section{6 測 定}

成形用媒液のうち流動パラフィンについて, 熱天秤に よる加熱減量曲線をとった。熱天称としては，リガク製 TG 8110 と同社製 TAS を組み合わせて使用した。試料 の全重量が $20 \mathrm{mg}$ の場合の分解能は $0.002 \mathrm{mg}$ である。 測定に当たり昇温速度を $2^{\circ} \mathrm{C} / \mathrm{min}$ とし，空気の組成に 近い混合ガス（酸素 $20 \%$ ，窒素 $80 \%$ ）を付属の炉の中 に毎分 $200 \mathrm{ml}$ 送り続けた。

2.5 節のようにして焼成を終えた試料について，焼成 収縮率，全気孔率，気孔径分布並びに比表面積を測定し， X 線回折を行った。全気孔率は試料の外法寸法, 重量, 真比重を測定し算出した. 気孔径分布と比表面積の測定 にはカルロ・エルボのポロシメーター2000を用いた。 水銀圧入圧力は 0.1 1 1600 気圧とし，圧力值から細孔径 への換算において用いた水銀のパラメータ一は，接触角 $140^{\circ}$ ，表面張力 $480 \mathrm{dyn} / \mathrm{cm}$ である ${ }^{6)}$. X 線回折装置と しては,リガク製 RAD- 2 型 X 線回折計を用いた。 X 線は $\mathrm{Cu} K \alpha$ 線で，測定条件は管球電圧 $40 \mathrm{kV}$ ，管球電流 $20 \mathrm{~mA}$ ，スキャン速度 $2^{\circ} 2 \theta / \mathrm{min}$ ，カウントフルスケー

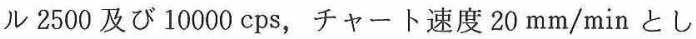
た。

\section{3. 結果と考察}

\section{1 成形用媒液の選択}

グリーン体積，グリーン強度，焼成後の亀裂の有無な ビの面を考慮して，成形用媒液を探索した，表 1 にはア ルミナ超微粉体 $10 \mathrm{~g}$ に対し, 各種の媒液をアルミナ粒
子表面積 $1 \mathrm{~m}^{2}$ 当たり $0.015 \sim 0.03 \mathrm{~g}$ 添加して成形して， 得られた試料の体積（ラミネーションが発生した場合を 除く)を示した。添加量がこの範囲であっても，加圧に 当たり系外に逃げる媒液の量には媒液の種類により差が あり,グリーン成形体の体積は変動した。また，ラミネ一 ションの発生する添加量の範囲も，媒液の種類により変 化した. 表に見られるように，グリーン成形体の体積は， シリコーン油，シクロヘキサン，アルコール，流動パラ フィンを用いて成形した場合において比較的大きかっ た。この結果は，原料粒子間あるいは原料粉体と媒液の 相互作用 ${ }^{7}$ の大小に関連があるものと考えられる。

グリーン強度が小さい亡, 得られたグリーン成形体の 一部が欠け落ちた。欠け落ちる量の大小により媒液とし ての適否が判定できた。

グリーン成形体を $1000^{\circ} \mathrm{C}$ に焼成した時点で，シリ コーン油，グリセリン，エチレングリコール及び水を成 形用媒液としてを添加した場合は，焼結体に亀裂が発生 しやすかった。エタノール，キシレン及びシクロヘキサ ンの場合は, 混合, 成形工程において蒸発しやすく不便 であり，オレイン酸の場合は，高気孔率の成形体が得ら れない。これに対し流動パラフィンとブタノールの場合

Table 1. Green volume of the compacts fabricated with various solvents without lamination (weight of alumina is $10 \mathrm{~g}$ ).

$\begin{array}{ll}\text { Solvent } & \text { Volume }(\mathrm{ml}) \\ \text { Ethylene glycol } & 7 \\ \text { Oleic acid } & 5 \sim 8 \\ \text { Glycerin } & 7 \\ \text { Butanol } & 6 \sim 9 \\ \text { Xylene } & 6 \sim 9 \\ \text { Water } & 7 \\ \text { Silicone oil (KF-96) } & 6 \sim 10 \\ \text { Cyclo hexan } & 7 \sim 8 \\ \text { Ethanol } & 7 \sim 9 \\ \text { Liquid paraffin }\left(14 \mathrm{cSt} / 40^{\circ} \mathrm{C}\right) & 7 \sim 12\end{array}$

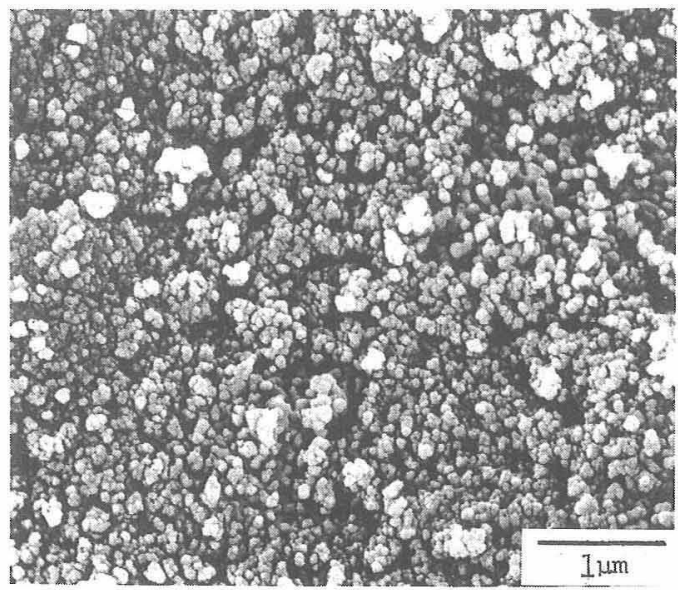

Fig. 1. SEM photograph of alumina compact of ultrafine powder fired at $1100^{\circ} \mathrm{C}$. 
は，混合などの工程における蒸発が少なく，表 1 にも見 られるように添加量の幅が広く, 焼成後の気孔率も高く, 成形用媒液として適していた。特に流動パラフィンは最 適と判断された. 図 1 には, 流動パラフィンを添加して 成形し, $1100^{\circ} \mathrm{C}$ に焼成して得られた焼成体の走查型電 子顕微鏡 (SEM) 写真を示す.

これらの結果をもとに，以下の実験では成形用媒液と して流動パラフィンを使用した.

\section{2 流動パラフィンの加熱減量曲線}

原料アルミナー流動パラフィン系成形体を焼成するに 当たって, 昇温速度の決定が必要となる，このため，熱 天秤により流動パラフィンの加熱減量曲線を求めた。但 し, 流動パラフィンを直接, 試料容器に取れば, 加熱中 に流動パラフィンが容器の壁をはい上がって逃げると考 えられたので, 原料アルミナとの混合物（重量 $20 \mathrm{mg}$ ） について加熱曲線を求め, 図 2 に示した。この際, 流動 パラフィンの量は，全体の約 $12 \%$ になるようにした。 この混合物はさらさらした粉末であった。

図から明らかなように，減量は $100^{\circ} \mathrm{C}$ 付近から始ま り， $300^{\circ} \mathrm{C}$ で $90 \%, 400^{\circ} \mathrm{C}$ で $92 \%$ に達し， $600^{\circ} \mathrm{C}$ 以上 で恒量となった。 2.5 節において $300^{\circ} \mathrm{C}$ までを慎重に昇 温するスケジュールを立てたのは，このような結果に基 ゔいている.

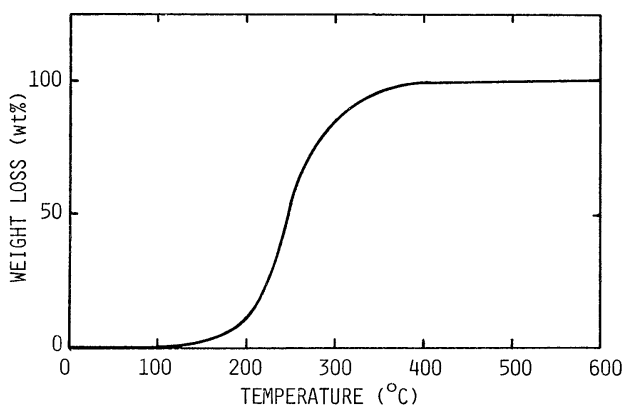

Fig. 2. TG curve of liquid paraffin.

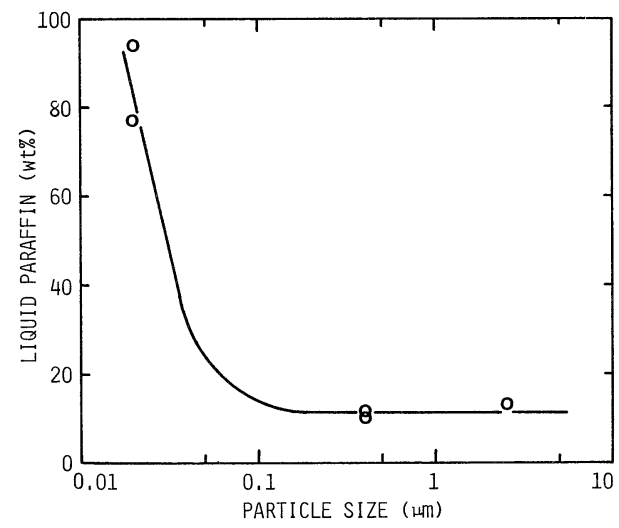

Fig. 3. Relation between the particle size of alumina and the amount of liquid paraffin.

\section{3 原料粒子径と成形用媒液量との関係}

図 3 には，粒子径の異なる原料アルミナに対し添加し た流動パラフィンの添加量を示した．粒子径が大きい原 料では，流動パラフィンの量は $10 \mathrm{wt} \%$ (dry basis) 程 度で少ないが，超微粉体の場合は 68 ～93 wt\%（体積比 では2.6〜3.6) に達した。しかし，これを原料粒子の 表面積 $1 \mathrm{~m}^{2}$ 当たりの量に換算すると, 超微粉体の場合 の方がかえって少なかった。

\section{4 原料粒子径と焼成体の気孔率との関係}

種々の粒子径のアルミナに対し，3.3 節の場合と同じ ように流動パラフィンを添加し， $300 \mathrm{~kg} / \mathrm{cm}^{2}$ の圧力で 成形， $1375^{\circ} \mathrm{C}$ に焼成した。 その結果得られた，多孔体 の全気孔率を図 4 に示した。図に明らかなように，粒子 径が 2.5 0.2 $\mu \mathrm{m}$ 付近までは, 気孔率が低くかつ粒子 径が小さくなるに従って, 気孔率は更に低下した。これ に対し粒子径が $0.02 \mu \mathrm{m}$ では，気孔率は著しく高い。

粒子直径の逆数に対し焼結速度が依存することは既に 知られており ${ }^{8)}$, 図 4 において, 粒子径が $0.2 \mu \mathrm{m}$ 以上 については従来の考元方がそのまま当てはまる.しかし， 粒子径が $0.1 \mu \mathrm{m}$ よりも著しく小さい場合には，前提条

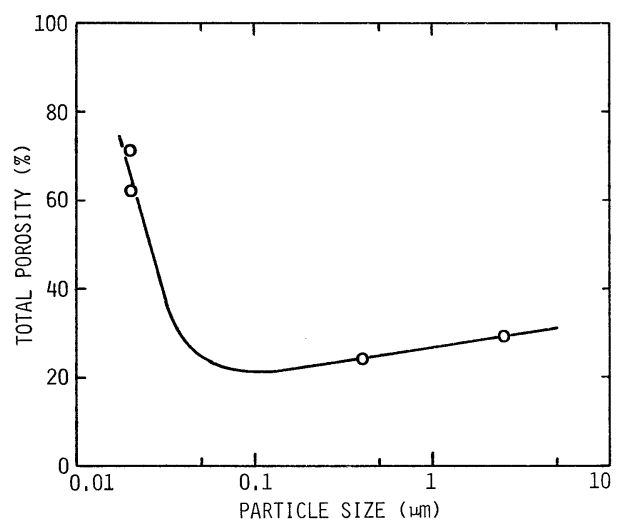

Fig. 4. Corelation between the particle size of alumina and the total porosity of fired compacts.

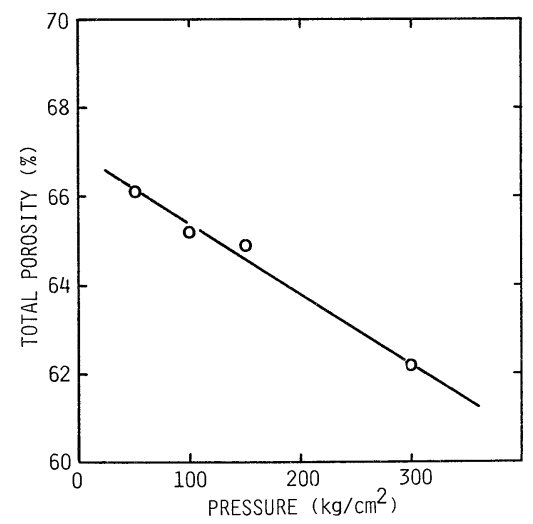

Fig. 5. Pressure dependence of the total porosity of the fired compacts. 
件が違うため適用することはできない，従来の理論は, 粒子が密に充填していることを前提にして焼結を論じて いるからである. 3.3 節にも述べたように, 本実験では, グリーン成形体における流動パラフィンの量が, 体積比 でアルミナの $2.6 \sim 3.6$ 倍に達するから, 各粒子は密に 接しているとは言えない.したがって, 密に接していれ ば当然焼結する温度に加熱しても, 焼結しない.

本研究の目的は, 高気孔率の焼結体を得ることにある から, 以後の実験はすべて, 成形用媒液を多く必要とす る超微粉体を用いて行った.

\section{5 気孔率の成形圧依存性}

焼結体の気孔率の成形圧依存性を調べるため, アルミ ナ超微粉体 $10 \mathrm{~g}$ と流動パラフィン $8 \mathrm{ml}$ (流動パラフィ ンの量は体積比でアルミナの 2.6 倍）との混合物を, 50 $\sim 300 \mathrm{~kg} / \mathrm{cm}^{2}$ の圧力で成形し, $1375^{\circ} \mathrm{C}$ に焼成した. 結 果を図 5 に示した。図に見られるように, 気孔率は圧力 の増大と共にほぼ直線的に減少した。ただし, 気孔率の 低下率は小さく, 圧力が $100 \mathrm{~kg} / \mathrm{cm}^{2}$ 増大するごとに約 $1.5 \%$ である.この結果は, 成形圧を増大させるに従い, 成形体外に逃げる流動パラフィンの量が僅かに増大する ことを意味する.

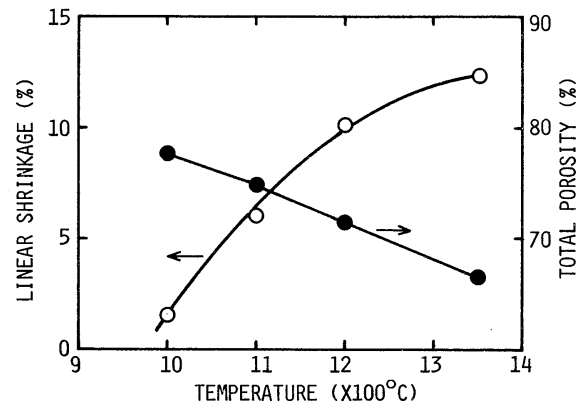

Fig. 6. Dependence of the firing shrinkage and the total porosity of the fired compacts on the firing temperature.

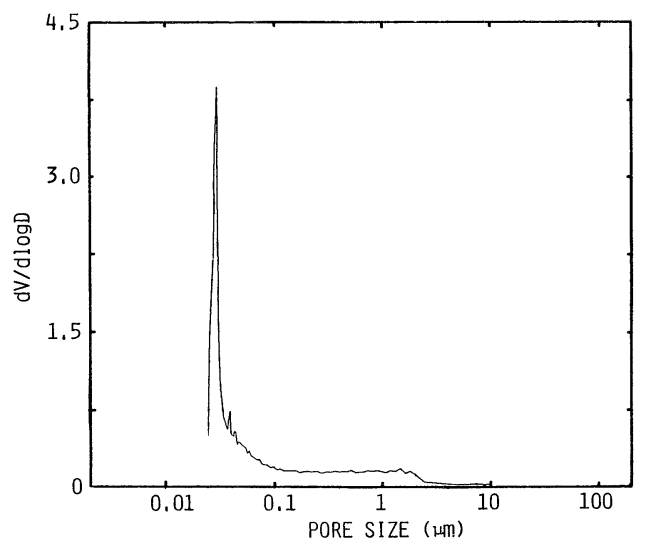

Fig. 7. Pore-size distribution of the alumina compact fired at $1000^{\circ} \mathrm{C}$.

\section{6 焼成収縮率の温度依存性}

他の条件を二定に保ったうえで, 焼成収縮率の温度依 存性を測定した。実験に当たり，原料 $10 \mathrm{~g}$ に対する成 形用媒液の量を $8 \mathrm{ml}$ に, 圧力は $300 \mathrm{~kg} / \mathrm{cm}^{2}$ に固定し, また焼成温度範囲は $1000^{\circ} \sim 1350^{\circ} \mathrm{C}$ とした．結果を図 6 に示した。図に見られるように，収縮は $980^{\circ} \mathrm{C}$ 付近か ら始まる．収縮率を $1200^{\circ} \mathrm{C}$ までの前半と $1350^{\circ} \mathrm{C}$ まで の後半とで比較すると, 前半のほうが収縮率の温度依存 性が大きい。

\section{7 気孔率の焼成温度依存性}

3.6 節と同様にして得られた試料について気孔率を測 定し, 焼成温度の関数として図 6 に並記した. 図に見ら

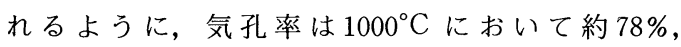
$1350^{\circ} \mathrm{C}$ においてなお $66 \%$ を示し， いずれにしても，高 気孔率の焼結体が広い温度範囲において得られた。

\section{8 気孔径分布}

気孔径分布は図 7～図 11 に示したように，焼成温度 $1000^{\circ} \sim 1350^{\circ} \mathrm{C}$ において $12 \mu \mathrm{m}$ 以下に分布した。焼成体 内の気孔を, 円筒状と仮定した場合の平均気孔径 ${ }^{8}$ は,

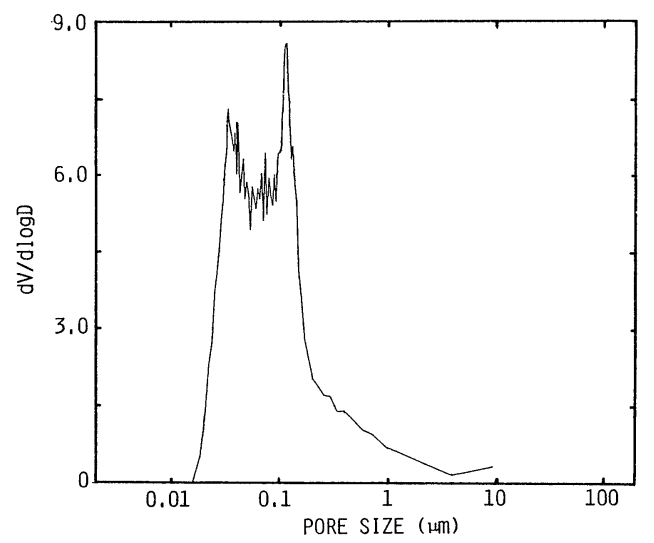

Fig. 8. Pore-size distribution of the alumina compact fired at $1050^{\circ} \mathrm{C}$.

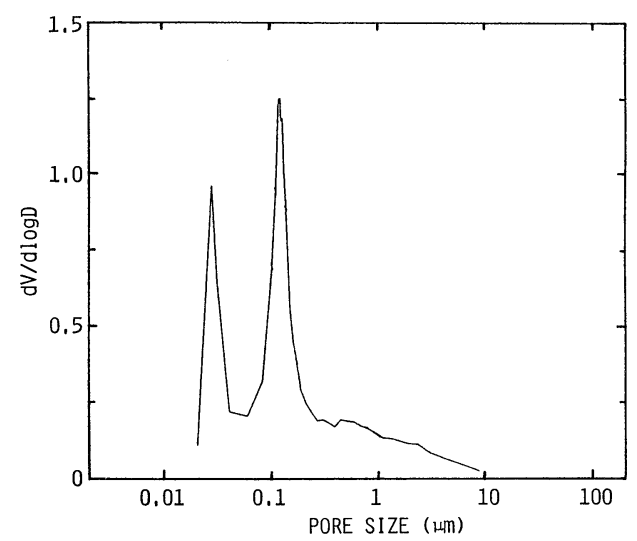

Fig. 9. Pore-size distribution of the alumina compact fired at $1100^{\circ} \mathrm{C}$. 
$1000^{\circ}, 1200^{\circ}, 1350^{\circ} \mathrm{C}$ において，それぞれ 0.050, 0.26 , $0.30 \mu \mathrm{m}$ であった. $1000^{\circ} \mathrm{C}$ では $0.03 \mu \mathrm{m}$ に鋭いピーク

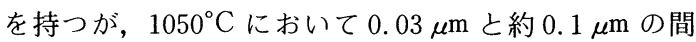
に分裂し, $1100^{\circ} \mathrm{C}$ においては完全に $0.03 \mu \mathrm{m}$ と 0.12 $\mu \mathrm{m}$ の二つのピークに分裂した. $1200^{\circ} \mathrm{C}$ では小さい方 の気孔径のピークが消え, 大きい方の気孔径のピークが 残った. また，残った気孔は焼成温度の上昇するに従っ てわずかに成長した。

この結果は, 従来の実験結果亡異なる，一般には，焼 成の過程で気孔径は大小二つのピークに分かれ，まず小 さい方が気孔容積を減じ，ついで大きい方も，次第に気 孔径を減じながら容積も減少する ${ }^{91}$, とされているから である.これは, 本実験に使用した原料が, 超微粉体で あること, 気孔率が従来の実験に比較して著しく大きい ことなどに起因すると考えられる．

\section{9 気孔径の分布と結晶構造の変化}

従来から, 気孔の成長ないし消滅は, 結晶構造の分解 又は粒成長との関連において考察されてきた ${ }^{10), 11)}$. 本実 験の場合, $1000^{\circ} \mathrm{C}$ 付近における結晶構造の変化との関

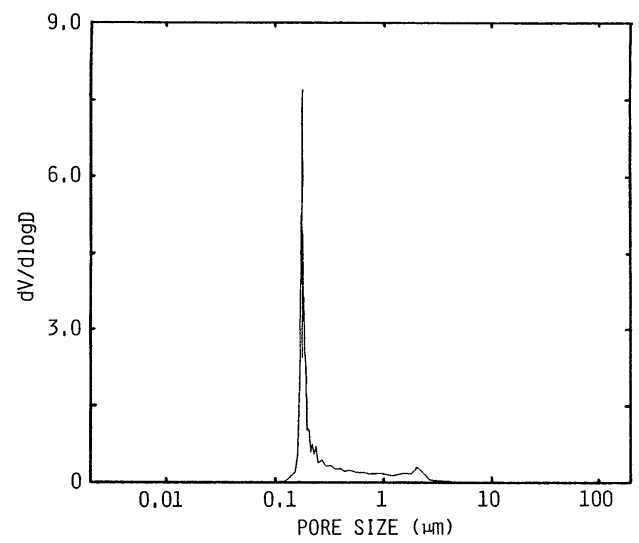

Fig. 10. Pore-size distribution of the alumina compact fired at $1200^{\circ} \mathrm{C}$.

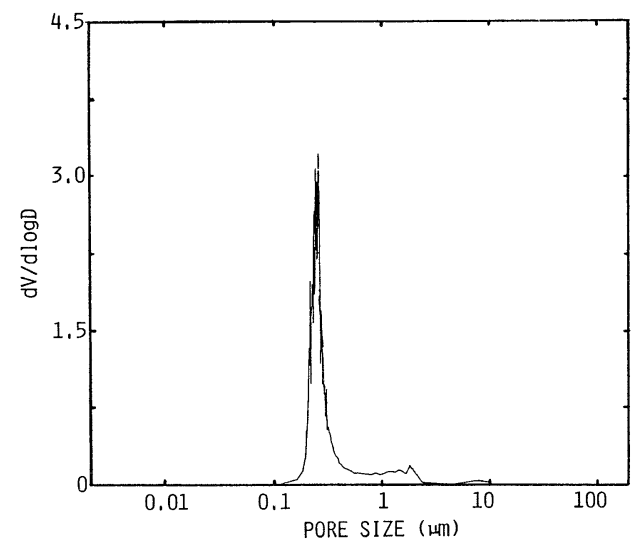

Fig. 11. Pore-size distribution of the alumina compact fired at $1350^{\circ} \mathrm{C}$.
連を見いだすため, X 線回折を行った. その結果を図 12 に示す. 図に見られるように, $1000^{\circ} \mathrm{C}$ に焼成された アルミナは $\gamma$ 型であるが， $1050^{\circ} \mathrm{C}$ では約 $30 \%$ に相当 する $\alpha$ 型アルミナが生成し, $1200^{\circ} \mathrm{C}$ ではほぼ完全に $\alpha$ 型アルミナに転移していた。これらの結果と 3.8 節の結 果とを比較すると, 結晶構造が $\gamma$ 型から $\alpha$ 型に変わる 温度は, 気孔径分布において多数のピークが現われる温 度と一致している.

\subsection{0 比表面積 $\left.{ }^{9}\right)$ 及び気孔体積の温度依存性}

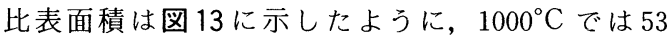
$\mathrm{m}^{2} / \mathrm{g}$ を示したが, 焼成温度の上昇するに従って急激に 小さくなった. また, 気孔体積もほぼ同様に減少した.

これらの結果は 3.8 節における, 比較的小さい気孔の 消滅に密接に関係していると考えられる.

\section{4. 結 論}

アルミナ超微粉体に対する加圧成形用媒液を創案し, また, 得られた成形体の諸特性を測定し, 次の結論に達 した。

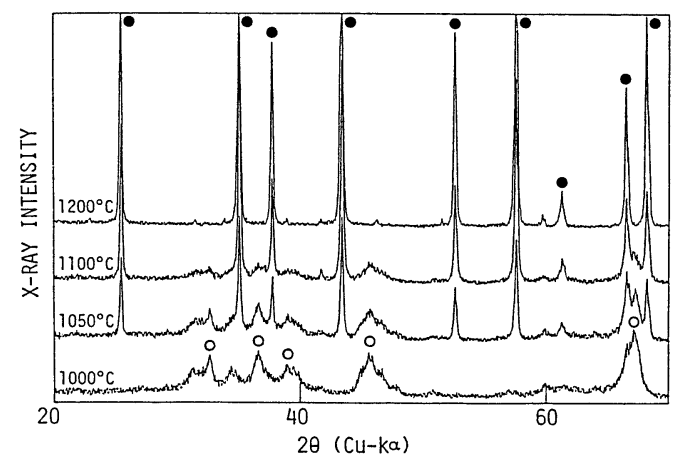

Fig. 12. Powder X-ray diffraction patterns of the compacts fired at $1000^{\circ}, 1050^{\circ}, 1100^{\circ}$ and $1200^{\circ} \mathrm{C}$. $\bigcirc: \gamma$-alumina, $\quad: \alpha$-alumina

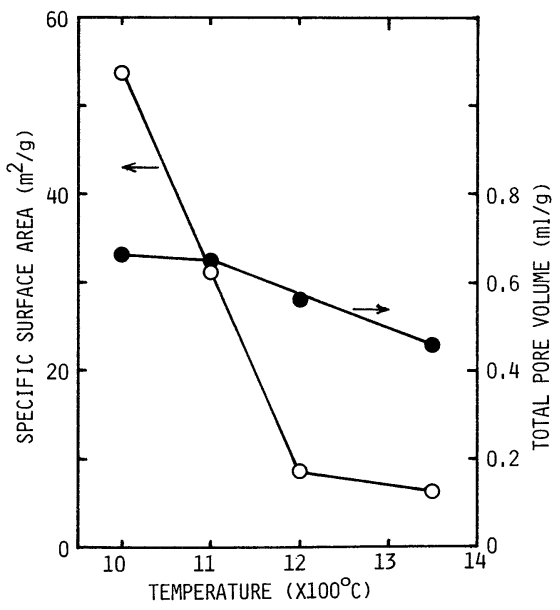

Fig. 13. Dependence of the specific surface area and the total pore volume on the firing temperature. 
（1）アルミナ超微粉体の加圧成形において, 成形用 媒液として流動パラフィンを多量に（アルミナの真の体 積の 2.6 3.6 倍)使用すれば, ラミネーションが少なく, 保形性のよい成形体が得られる.

（2）グリーン成形体を焼成し，亀裂のない微細気孔 性多孔体を得た。気孔径は $12 \mu \mathrm{m}$ 以下に分布し, その 平均気孔径は $1000^{\circ} \mathrm{C}$ において $0.050 \mu \mathrm{m}$ であった.こ れは,グリーン成形体に多量に添加された, 流動パラフィ ンに起因する。

(3) $1050^{\circ} \mathrm{C}$ において気孔径分布は, 多数のピーク に分かれ, 並行して原料アルミナは $\gamma$ 型から $\alpha$ 型へ転 移した. $1200^{\circ} \mathrm{C}$ 以上では気孔径分布は単一のピークを 示した。

（4）焼成体の気孔率は， $1000^{\circ} \mathrm{C}$ において約 $78 \%$, $1350^{\circ} \mathrm{C}$ において約 $66 \%$ で，また比表面積はそれぞれ 53 及び $6 \mathrm{~m}^{2} / \mathrm{g}$ であった.

（5）焼成体の気孔率の成形圧依存性は小さく,100 $\mathrm{kg} / \mathrm{cm}^{2}$ 当たり約 $1.5 \%$ であった.
謝辞 本研究をまとめるに当たり, 大阪工業技術試験所 有機機能材料部・林 和子博士からは, 貴重な助言を頂いた。 ここに感謝の意を表します.

\section{文献}

1) 加藤昭夫, 明石和夫, 化学総説 No. 4, “超微粒子一科学 と応用”, 学会出版センタ- (1985) pp.17-45.

2) 古井康郎, 杉本文雄, 特公昭 59-43433.

3) 和田伸彦, 工業材料, 31, 3-6 (1983).

4) 成宮恒彦, 坂田純二, 工業材料, 26, 57-61 (1978).

5）福島繁義, 水野正晃, 古賀秀昭, 特開昭 56-145153.

6) H. L. Ritter and L. C. Drake, Ind. Eng. Chem. Anal. Ed. , 17, 782-86 (1945).

7) A.S. Michaels, "Ceramic Fabrication Processes (W. D. Kingery Editor)”, John Wiley \& Sons, Inc., New York (1958) pp. 23-31.

8) W.D. Kingery, ibid., pp. 131-43.

9）近藤連一編著, “多孔材料”, 技報堂 (1986) pp. 8-43.

10) Z. Juhasz, Tonind. Ztg. Keram. Runds., 86, 512-17 (1962).

11) W. D. Kingery and B. Francois, J. Am. Ceram. Soc., 48, 546-47 (1965). 